\title{
Should the clinical study on opioid-induced cough continue?
}

\author{
Jong In Han \\ Department of Anesthesiology and Pain Medicine, School of Medicine, Ewha Womans University, Seoul, Korea
}

Since Böhrer et al. [1] reported in 1990 that administering fentanyl through a central venous catheter induces the cough reflex, it has become well-known that remifentanil and fentanyl used for inducing general anesthesia cause a cough in various types of clinical situations. This has led to many clinical studies [2-4] thus far, and the research paper of Yoo et al. [5] is also included in this group.

The proposed mechanisms through which opioids induce a cough are as follows: (1) pulmonary chemoreflex resulting from stimulation of C-fiber receptors (J receptors) [1], (2) stimulation of irritant receptors (rapidly adapting receptors) from deformation of the tracheobrochial wall by tracheal smooth muscle constriction [6], (3) the release of histamine from lung mast cells [7], and (4) the sudden adduction of the vocal cords or supraglottic obstruction by soft tissue caused by opioid-induced muscle rigidity [8]. Based on these mechanisms, many efforts have been made to reduce the cough reflex induced by opioid agents, and it has been reported that terbutaline (a selective beta-2 agonist) [9], salbutamol [7], lidocaine [10], ephedrine [11], clonidine [12], ketamine [13], and dexamethasone [5] are effective in reducing fenanyl-induced cough (FIC) or remifentanil induced cough (RIC).

However, Elcock [14] referred to the paper of Hung et al. [2] that was included in the 2010 volume of Anesthesia and raised the question whether fentanyl really induces a cough with such a high frequency (18-65\%) in clinical settings. Also, he stated that his experience of using fentanyl clinically (administering $30 \mathrm{mg}$ of propofol when administering $100 \mathrm{ug}$ of fentanyl before inducing anesthesia) did not induce a cough, and that he was perplexed that research on fentanyl-induced cough continues, and that in actuality, it is not problematic except for pediatric patients. As a result, he asserted that it is meaningless to conduct studies on this phenomenon because, at least for adults, the commonly used dosage of fentanyl does not pose any actual problem.

There are also recent reports that recommend not administering the medicine because FIC and RIC are temporary and the pre-treatment itself can cause problems [15]. Moreover, there are studies showing good results from adjusting the administration method of fentanyl and remifentanil so that their blood concentration levels increase gradually, because it is the sudden rise of their blood concentration levels that trigger the cough inducing mechanisms. There are also reports of reducing coughs by administering fentanyl slowly [16] or by administering a small amount in advance, so that there is not a sudden increase in concentration [2]. Also, there are studies that coughs are reduced by administering remifentanil in separate doses [17] and by limiting the peak plasma concentration when infusing remifentanil by TCI [18]. The paper of Ambesh et al. [3] that was published in the British Journal of Anesthesia in 2010 also reported significantly reduced cough (32\% to $4 \%$ ) induced by $2.5 \mathrm{ug} / \mathrm{kg}$ of fentanyl if a huffing maneuver was done before inducing anesthesia.

Thus, fentanyl and remifentanil induced cough can be significantly reduced even without medicinal prevention. The continuous repetition of the same form of clinical study for more than 20 years seems meaningless even though I do not totally agree with Elcock's opinion. I have also published a paper [19] in 1996 reporting that administration of fentanyl to pediatric patients leads to high-dosage dependency and frequent coughs, and administering lidocaine in advance reduces coughs. In 2010 I published a paper about the impact of

Corresponding author: Jong In Han, M.D., Ph.D., Department of Anesthesiology and Pain Medicine, Ewha Womans University Mokdong Hospital, 911, Mok-dong, Yangcheon-gu, Seoul 158-710, Korea. Tel: 82-2-2650-5559, Fax: 82-2-2655-2924, E-mail: hanji@ewha.ac.kr (c) This is an open-access article distributed under the terms of the Creative Commons Attribution Non-Commercial License (http:// creativecommons.org/licenses/by-nc/3.0/), which permits unrestricted non-commercial use, distribution, and reproduction in any medium, provided the original work is properly cited. 
FIC on endotracheal intubation in pediatric patients [4].

Although many studies have been carried out over decades, the mechanism of FIC or of RIC has not yet been found. Therefore, I believe it is more useful shed light on why a sudden increase in blood concentration induces a cough, instead of conducting studies about reducing its clinical frequency.

\section{References}

1. Böhrer H, Fleischer F, Werning P. Tussive effect of a fentanyl bolus administered through a central venous catheter. Anaesthesia 1990; 45: 18-21.

2. Hung KC, Chen CW, Lin VC, Weng HC, Hsieh SW. The effect of preemptive use of minimal dose fentanyl on fentanyl-induced cough. Anaesthesia 2010; 65: 4-7.

3. Ambesh SP, Singh N, Gupta D, Singh PK, Singh U. A huffing manoeuvre, immediately before induction of anaesthesia, prevents fentanyl-induced coughing: a prospective, randomized, and controlled study. Br J Anaesth 2010; 104: 40-3.

4. Han JI, Lee H, Kim CH, Lee GY. The frequency of fentanyl-induced cough in children and its effects on tracheal intubation. J Clin Anesth 2010; 22: 3-6.

5. Yu MS, Kim JY, Kim HY. Intravenous dexamethasone pretreatment reduces remifentanil induced cough. Korean J Anesthesiol 2011; 60: 403-7.

6. Yasuda I, Hirano T, Yusa T, Satoh M. Tracheal constriction by morphine and by fentanyl in man. Anesthesiology 1978; 49: 117-9.

7. Agarwal A, Azim A, Ambesh S, Bose N, Dhiraj S, Sahu D, et al. Salbutamol, beclomethasone or sodium chromoglycate suppress coughing induced by iv fentanyl. Can J Anaesth 2003; 50: 297-300.

8. Benthuysen JL, Smith NT, Sanford TJ, Head N, Dec-Silver H. Physiology of alfentanil-induced rigidity. Anesthesiology 1986; 64:
440-6.

9. Lui PW, Hsing $\mathrm{CH}$, Chu YC. Terbutaline inhalation suppresses fentanyl-induced coughing. Can J Anaesth 1996; 43: 1216-9.

10. Kim JY, Park KS, Kim JS, Park SY, Kim JW. The effect of lidocaine on remifentanil-induced cough. Anaesthesia 2008; 63: 495-8.

11. Lin CS, Sun WZ, Chan WH, Lin CJ, Yeh HM, Mok MS. Intravenous lidocaine and ephedrine, but not propofol, suppress fentanylinduced cough. Can J Anaesth 2004; 51: 654-9.

12. Horng HC, Wong CS, Hsiao KN, Huh BK, Kuo CP, Cherng CH, et al. Pre-medication with intravenous clonidine suppresses fentanylinduced cough. Acta Anaesthesiol Scand 2007; 51: 862-5.

13. Kim JY, Kim JY, Park SY, Jung WS, Kawk HJ. Effect of low dose ketamine to prevent remifentanil-induced cough: a randomize, double-blind, placebo controlled trial. Korean J Anesthesiol 2009; 56: 624-7.

14. Elcock DH. Fentanyl-induced cough. Anaesthesia 2010; 65: 536-7.

15. Schlimp CJ, Wiedermann FJ. Dose fentanyl-induced cough justify pre-treatment with iv lidocaine 2 mg.kg-1. Can J Anaesth 2005; 52: 207.

16. Lin JA, Yeh CC, Lee MS, Wu CT, Lin SL, Wong CS. Prolonged injection time and light smoking decrease the incidence of fentanylinduced cough. Anesth Analg 2005; 101: 670-4.

17. Lim JH, Ryu SJ, Lim YS. The incidence of cough induced by remifentanil during anesthetic induction was decreased by graded escalation of the remifentanil concentration. Korean J Anesthesiol 2010; 58: 117-21.

18. Kim JY, Nahm FS, Park YO. Limiting peak plasma concentration effectively decreases remifentanil-induced coughing during targetcontrolled infusion. Anaesth Intensive Care 2008; 36: 746.

19. Han JI, Lee GY, Lee CH, Oh EJ. Tussive effect of intravenous fentanyl administration and antitussive effect of lidocaine. Korean J Anesthesiol 1996; 31: 462-5. 